УДК: 378.147.091.3:811.111'373:61

DOI: 10.37026/2520-6427-2020-104-4-64-67
Агнесса ТОМАШЕВСЬКА,

кандидат педагогічних наук, викладач кафедри іноземних мов

Буковинського державного медичного університету, м. Чернівиі

Людмила РУСАЛКІНА,

доктор педагогічних наук,

доиент кафедри іноземних мов

Одеського національного медичного університету

\title{
ТЕХНОЛОГІЯ ФОРМУВАННЯ У МАЙБУТНІХ СТУДЕНТІВ-ФАРМАЦЕВТІВ УМІНЬ САМОСТІЙНОГО ВИВЧЕННЯ ФАХОВОЇ МЕДИЧНОЇ ЛІТЕРАТУРИ
}

У статті аналізується технологія відбору лексичного корпусу як одиниць дидактичного текстового матеріалу для формування умінь самостійного читання (guided-unguided work) медичної літератури студентами-фармацевтами. Визначено базові критерії відбору англійської фармачевтичної лексики (функиіональність, уживаність, частотність, тематичність та врахування професійної сфери спілкування), які інтегрально корелюються із змістовими та прочесуальними компонентами цүільовоі робочої програми навчання.

Ключові слова: лексична одиниия, текст, критерії відбору, самостійне читання, студенти-фармаиевти.

The paper presents the selecting technology of lexical thesaurus with professional potential as units of the didactic textual materials for students-pharmacists self-directed reading skills (guided-unguided work) forming; grounded on the modern Ukrainian investigations analyzing and focused on the ESP teaching the key selected criteria of English pharmaceutical vocabulary (use and frequency, topicality, consideration of the professional communication sphere, functionality), which integrally correlate with content and procedural components of the partial working program teaching have been determined. Considered in the paper are: the formation of lexical awareness in reading throughout three stages: introduction, whereby the students get acquainted with lexical units in and beyond the context, as well as develop their lexical consciousness; training, which promotes students' automatic work with new vocabulary; application in the process of reading and speaking; the criteria for assessing the level of prospective pharmacists' mastering professionally oriented English lexical competence in reading, the accuracy of understanding, the correctness of guessing the meaning of a lexical unit, the adequacy of usage.

Key words: lexical awareness, skills, unit, text, independent study, assessment, criteria, students-pharmacists.
Постановка проблеми. Англомовну лексичну компетентність у читанні та говорінні (далі - АЛКЧГ) майбутніх фармацевтів визначено як здатність фахівця адекватно розуміти у ході читання та використовувати в процесі говоріння лексичні одиниці, у тому числі термінологічні, з метою досягнення особистісно та професійно значущих комунікативних цілей.

Серед складників іншомовної комунікативної компетентності фахівців будь-якої галузі чи не найважливішу роль відіграє лексична компетентність у читанні та говорінні, адже саме вона першочергово забезпечує отримання інформації із друкованих джерел, успішну реалізацію цілей спілкування з іноземними колегами, партнерами чи клієнтами.

Концептуальними ідеями досліджуваної проблеми є положення комунікативно-когнітивного, рефлексивного та інтегрованого підходів. Так, комунікативно-когнітивний підхід забезпечує процес оволодіння АЛКЧГ, порівняння лексичних одиниць у різних мовах (українській, латинській та англійській) 3 метою знаходження аналогій, що полегшує процес навчання, стимулює когнітивну активність студентів, вирішення реальних проблем та завдань професійного спілкування. Інтегрований підхід зумовлює формування англомовної лексичної компетентності у читанні та говорінні інтегровано з дисциплінами фаху. Рефлексивний підхід реалізується шляхом цілеспрямованого формування рефлексивних умінь студентів, заохочення їх до рефлексивної самооцінки результатів власної діяльності, порівняння результатів самооцінювання з оцінкою викладача, забезпечення можливості самокорекції, створення умов для розвитку автономії студентів.

Із метою з'ясування результатів самооцінки студентами власних знань англійської фармацевтичної лексики ми провели опитування 141 студента на основі емпіричного методу наукового спостереження за процесом навчання на кафедрі Буковинського державного медичного університету та вивчення досвіду викладачів (2019 р.). Так, 87\% респондентів незадоволені рівнем володіння англійською мовою, 68\% вказали 3-поміж труднощів читання - незнання лексичних одиниць. 
Гіпотеза означеного дослідження грунтується на розгляді процесу вивчення англійської галузевої мови (ESP) як низки дидактичних кроків від мовних знань (language knowledge) до набуття умінь професійного читання (reading skill).

Мета дослідження - обгрунтувати контент фахового навчального матеріалу для оволодіння майбутніми фармацевтами лексичними навичками самостійного читання медичної літератури субмови «Фармація».

Зазначене вище зумовлює необхідність визначення таких завдань:

- проаналізувати сучасні вітчизняні та зарубіжні наукові джерела $з$ досліджуваної проблеми;

- описати сутність технології набуття студентами лексичних знань у межах спеціальності та мовної усвідомленості в процесі самостійного читання;

- за визначеними критеріями окреслити реалізацію відбору англійських фармацевтичних одиниць відповідно до їх типології для укладання словника-мінімуму з латинськими та українськими відповідниками.

Аналіз наукових досліджень і публікацій. Проблема розробки ефективної технології формування у студентів немовних вишів лексичних навичок самостійного читання англійської фахової літератури $\epsilon$ різноаспектною і була предметом наукових розвідок багатьох українських та зарубіжних науковців. Сутність нашого розуміння навчання англійської мови професійного спрямування суголосна 3 інтерпретацією означеного концепту вченими 60 -х років XX століття, зокрема, термін «англійська мова за професійним спрямування» (ESP) повинен містити у собі структурний елемент «термінолект», який $є$ термінологічним ядром певної професійної галузі, а його лінгвістичне втілення забезпечується термінологічним тезаурусом - складовою соціального фахового мовлення, у нашому випадку - професійного дискурсу. У той період було доведено інтегрованість лексичного тезаурусу й усного дискурсу J. Neu, 1986; J. Richards, 1976; вокабуляру та письма L. Selinker, 1981; J. Swales, 2000; розгляду слів як структурних (будівельних блоків), на яких формується знання іноземної мови як другої (D. Seal); професійного лексикон-читання (intensive \& extensive reading) як засобу оволодіння навчаючим потенційним словником у контексті читання (D. Brown, 1974; F. Dubin, 1986).

Автори О. І. Дуда, О. Ф. Кондратенко, Л. Г. Русалкіна трактують засоби оптимізації запам'ятовування лексики та іiі актуалізації шляхом навчання читанню як важливої частини когнітивної бази студентів, створення дійових програм комунікативного професійного навчання в межах спеціальності (functional nature of communication), а також опису контенту відповідного навчального методу (a learning-centered approach), що спрямований на потреби студента (D. Bycina, 1985; T. Hutchinson \& A. Waters, 1987).

Сучасні науковці Т. І. Горпінич, В. С. Доля, Е. А. Долгая, Л. І. Черняк визнають важливу роль реалізації формату контекстного навчання із різних сфер професійно-комунікативної діяльності майбутніх фармацевтів. О. М. Шамов обгрунтовує ідею, згідно 3 якою лексична компетентність є здатністю визначати контекстуальне значення лексичної одиниці, встановлювати національний компонент у значенні слова $[11$, с. 98]. А. В. Палецька-Юкало розглядає лексичну компетентність як здатність на основі засвоєних лексичних знань, сформованих лексичних навичок та лексичної усвідомленості розпізнавати та сприймати лексичну одиницю [10, с. 29].
Проте у вітчизняній методиці лише незначна кількість наукових досліджень присвячена розвитку мовленнєвої діяльності майбутніх фармацевтів. Зокрема, T. I. Горпініч запропонувала методику формування професійно орієнтованої англомовної компетентності у читанні майбутніх фармацевтів із урахуванням індивідуально-когнітивних стилів навчання [4, с. 223], а Н. Є. Шпак - методику навчання розуміння, вилучення та використання інформації з іншомовних джерел у монологічному висловлюванні майбутнього провізора.

Отже, нерозробленою залишається методика формування у майбутніх фармацевтів лексичної компетентності в читанні та говорінні у процесі самостійної роботи. Зазначене вище і зумовлює актуальність обраної теми.

Виклад основного матеріалу. Аналіз науковометодичних джерел (К. Я. Кусько, Н. П. Жовтюк, Л. С. Бірецька, І. П. Задорожна, 3. К. Соломко, Л. В. Крисак, А. М. Котловський, Л. Т. Русалкіна) та досвід роботи колективу кафедри іноземних мов Буковинського державного медичного університету (далі - БДМУ) дозволяє обгрунтувати власну експериментальну траєкторію дидактичних дій самостійного англомовного навчання професійного спрямування студентів-фармацевтів $з$ отримання лексичних знань та їх використання.

Логіка дослідження зумовила алгоритм іiї змістового складу: залежність структури від цілей навчання впровадження базових знань загальної англійської мови - відповідність специфіки навчальних тем конкретній професійній сфері - врахування їх лексичного наповнення, формату текстів, реальних типових ситуацій - розробка і коригування програми курсу залежно від змін у галузі та умов навчання.

Розроблена технологія передбачає три етапи формування англомовної лексичної компетентності в читанні під час самостійної роботи: ознайомчий, який вводить нові лексичні одиниці, демонструє особливості їх уживання; тренувальний - автоматизація дій студентів із новими лексичними одиницями на рівні слова, словосполучення речення, понад фразової єдності; етап застосування - активізація на рівні тексту.

Розвиваючи ідеї дослідників щодо проблеми, виокремлюємо наступний контент лексичних знань: особливості лексичної системи іноземної та рідної мов; значення лексичної одиниці; правила їі сполучуваності, еквівалентність / безеквівалентність між термінологічними лексичними одиницями англійської та рідної мов; антоніми, синоніми, правила словотвору.

Серед процедурних виділяємо знання: як уживати, здійснювати морфемний аналіз та правильно сполучувати вивчені лексичні одиниці $[14$, с. 70$]$.

У науковій розвідці сучасних педагогів формування лексичних навичок читання трактується здатністю реалізовувати синтезовану дію із сприйняття, розпізнавання і розуміння лексичних одиниць у тексті [7, с. 24]. Репродуктивні навички І. П. Задорожна визначає як навички правильного вживання іншомовних лексичних одиниць у різних ситуаціях з урахуванням реєстру мовлення, а тренінг самостійного читання тексту із фаховим потенціалом обумовлює, за твердженням науковця, набуття рецептивних та репродуктивних лексичних навичок [14, с. 69-75].

Процес пізнання лексичних знань передбачає оволодіння лексичним матеріалом, складовою якого у контексті підготовки фахівців фармацевтичної галузі $\epsilon$ терміни. Термінологічний пласт англійської лексики включає поняття, значення яких формуються у рамках 
вербально-когнітивної ділянки різних типових взаємовідносин, наприклад: фармацевт - постачальник; фармацевт - керівник підприємства; фармацевт - колектив; фармацевт - фармацевт; фармацевт - покупець. В умовах іншомовного спілкування найактуальнішими, на нашу думку, є взаємовідносини фармацевт фармацевт, фармацевт - покупець, клієнт, а також фармацевт - постачальник. Існують дані, згідно з якими, фармацевтичний ринок кожного року зростає на 10-12 \%. Відповідно швидкими темпами збільшується і споживання лікарських засобів. Упродовж десятиліття з'явилося понад $60 \%$ нових медичних препаратів та відбулось істотне оновлення навяних [4, с. 222-225]. Аналіз фахових текстів, на нашу думку, зумовив висновок, що, хоча в них зазвичай вживається значна кількість термінів, труднощі їх розуміння дещо перебільшені, оскільки невелика кількість термінів вимагає пояснення (наприклад, в коментарях), а більшість iз них є інтернаціональними (наприклад, bacillus, virus, vitamin et al) i мають латинське походження.

Вивчаючи латинську мову, студенти опановують значну кількість термінів. За даними науковців, із 2000 англійських медичних термінів 63 \% становлять греко-латинські запозичення, причому латинських запозичень у три рази більше, ніж грецьких - 985 і 307 одиниць відповідно. Таким чином, оволодіння лексикою передбачає опору на латинські відповідники. Іншими словами, термінологія, яка засвоєна в процесі вивчення латинської мови, є певною основою для оволодіння новою лексикою англійськоі мови.

Перш ніж розглянути критерії відбору лексичного матеріалу, необхідно описати процедуру відбору термінологічних одиниць. Керуючись загальнометодичними принципами відбору, які розроблені в повній мірі та перевірені з часом на практиці, лише доповнимо існуючі для вирішення завдань нашого дослідження. Процедура відбору термінологічних одиниць передбачає аналіз підручників для вивчення англійської субмови «Фармація» стосовно лексичного матеріалу, словників, оцінювання фахових текстів щодо насиченості фармакологічними термінами, відібраними попередньо під час читання інших текстів у межах тем програми, у тому числі опрацьованих на аудиторних заняттях.

Дослідники (І. Л. Бім, Ю. І. Пассов, І. А. Попова, Л. І. Черняк, С. П. Шатилов) вказують, що одиницею відбору навчального матеріалу можуть бути словоформи, вільні і сталі словосполучення, речення, тексти для читання та говоріння. 3 урахуванням методичної класифікації іншомовної лексики медичної сфери К. О. Митрофанової, відібрані лексичні одиниці розділено на типологічні групи за критерієм подібності в англійській, латинській, українській мовах: графічної форми та однаковим значенням у трьох мовах (наприклад, barium $\leftrightarrow$ Barium $\leftrightarrow$ барій); графічної форми у двох мовах (англійській і латинській чи англійській та українській) і однакові за значенням (наприклад, boron $\leftrightarrow$ Borum $\leftrightarrow$ бор) чи які мають компоненти, подібні в трьох мовах, що сприяють розумінню значення лексичної одиниці або іiі запам'ятовуванню (наприклад, caffeine sodium benzoate $\leftrightarrow$ coffeinum-natrii benzoas $\leftrightarrow$ кофеїн-бензоат натрію); лексичні одиниці, не подібні в трьох мовах за графічною формою, але однакові за значенням (наприклад, bile $\leftrightarrow$ chole $\leftrightarrow$ жовч) [5, с. 168]. Найлегшою для засвоєння є лексика, що належить до першої типологічної групи, оскільки основою для запам'ятовування слугують відповідники в українській та латинській мовах.

О. М. Бастрікова для відбору лексики у навчанні мови фаху пропонує такі характеристики: частотність вживання слова та актуальність поняття; словотворчу цінність; ймовірність використання у подальшій діяльності студента.

Професійну спрямованість, адекватність навчального матеріалу цілям навчання, частотність, практичну необхідність, тематичність Л. Ф. Манякіна, Ю. О. Семенчук розглядають як важливі умови відбору фахової лексики.

Під критеріями відбору розуміємо вимоги, яким повинні відповідати обрані одиниці відбору. Проаналізуємо критерії відбору лексики у навчанні мови фаху, які виокремлюють сучасні дослідники, а саме: уживаності та частотності, тематичності, функціональності, наявності відповідника в латинській мові, врахування професійної сфери спілкування. Наведені критерії орієнтовані на здійснення їх засвоєння студентом на певному етапі навчання.

Критерій тематичності передбачає відбір професійної лексики згідно $з$ тематикою, рекомендованою програмою. Зазначимо, що теми, котрі окреслюють відбір лексичних одиниць, ідентичні із темами для відбору фахових текстів. У статті (див табл.) наведені приклади лексичних одиниць, відібраних за темами «Лікарські рослини» та «Лікарські форми».

Таблиия

\section{Приклади відібраних лексичних одиниць за темами}

\begin{tabular}{|c|l|}
\hline Теми & \multicolumn{1}{|c|}{ Приклади відібраних лексичних одиниць } \\
\hline $\begin{array}{c}\text { Лікарські } \\
\text { рослини }\end{array}$ & $\begin{array}{l}\text { aloe, althea, balm, barley, belladonna, bird cherry, burdock, calendula, circassian } \\
\text { walnut, coltsfoot, cranberry, parsley, plantain, raspberry, rhizome, root, sage, sea } \\
\text { buckthorn, seeds of sweet almonds, shoot, sorrel, spring adonis, tar, thyme, valerian. }\end{array}$ \\
\hline $\begin{array}{c}\text { Лікарські } \\
\text { форми }\end{array}$ & $\begin{array}{l}\text { capsule, concentrate of bitter water, conifer extract in briquettes, cream, crystal, } \\
\text { decoction, diluted, dissolved, distilled, dragée, dry extract of wild carrot fruit, ear drops, } \\
\text { elixir, emulsion, ointment, suppository, suspension, syrup, tablet, tincture. }\end{array}$ \\
\hline
\end{tabular}

Ще одним критерієм, за яким пропонуємо відбирати лексичні одиниці, є наявність відповідника в латинській мові. Такий відповідник часто полегшує запам'ятовування лексичної одиниці, оскільки на першому курсі студенти вивчають латинську мову.

Наведемо декілька прикладів лексичних одиниць та їх відповідників у латинській мові 3 укладеного нами словника-мінімуму: brilliant green $\rightarrow$ Viride nitens, ntis $\mathrm{n} \rightarrow$ зеленка; bulb $\rightarrow$ bulbus, i m $\rightarrow$ цибулина; burdock $\rightarrow$ Arctium lappa, ae $\mathrm{f} \rightarrow$ лопух; buttercup $\rightarrow$ Ranunculus, i $\mathrm{m} \rightarrow$ жовтець et al.

При відборі лексичних одиниць вважаємо важливим використовувати критерій урахування професійної сфери спілкування, оскільки тематикою дослідження передбачено формування лексичної компетентності в читанні та говорінні.

Критерій функціональності передбачає ряд характеристик: сполучуваність лексичної одиниці, іiі семантичну, словотворчу цінність, багатозначність. 
Ми повністю погоджуємося із твердженням А. Кравченко, що в умовах формування лексичної компетентності в читанні доцільно брати до уваги критерій сполучуваності, метою якого є добір лексики, що має високий коефіцієнт валентності слова у мовленні, звертати увагу на семантичний діапазон лексичної одиниці, який може змінюватися залежно від іiі сполучуваності [9, с. 105].

Наступний критерій уживаності та частотності визначає необхідний обсяг відбору термінологічних одиниць (далi - TO), який обумовлений тим, наскільки часто термін вживається у фахових текстах та ситуаціях спілкування. При цьому, дотичною до нашого визнання $є$ думка Ю. І. Пассова, що при відборі потрібно враховувати не глобальну частотність, а частотність для вирішення мовленнєвого завдання [6, с. 39]. Дослідники обгрунтовують різну кількість ТО. Так, Й. М. Берман доводить, що 200 одиниць спеціальної термінології є оптимальною для розуміння фахового тексту [2, с. 232], Н. Г. Вишнякова - 720 ТО [3, с. 16], а в укладеному Ю. О. Семенчуком словнику-мінімумі для студентів-економістів відібрано 434 лексичні одиниці [8, с. 81]. Екстраполюючи точку зору дослідників, зосереджуємося на ідеї авторів, що кількість лексичних одиниць зумовлюється достатністю для розуміння професійних текстів та спілкування у межах тематики.

Таким чином, аналіз сучасних досліджень, професійних потреб майбутніх фармацевтів, проведене опитування студентів та викладачів, вивчення спеціалізованих підручників дали можливість визначити предметний зміст навчальної траєкторії викладання англійської мови із фаховим потенціалом, певні критерії добору дидактичного матеріалу для набуття лексичних знань самостійного читання 3 урахуванням специфіки, типології ТО фармацевтичної галузі, психологічні особливості їх засвоєння.

Висновки та перспективи подальших досліджень. Отже, у статті проаналізована технологія формування в майбутніх фармацевтів умінь самостійного читання фахової літератури, що забезпечує автоматизацію дій студентів із новими лексичними одиницями на рівні слова, словосполучення, речення, понад фразової єдності та активізацію форм роботи на рівні тексту. Технологія призначена для впровадження у межах дисципліни «Англійська мова». Суб'єктом навчання є студенти, які здобувають освіту за спеціальністю 226 «Фармація, промислова фармація».

Нами виділено покрокові етапи оволодіння лексичними знаннями: презентація тематичного блоку лексичних одиниць, їх типологія, порівняння в трьох мовах, розуміння, запам'ятовування, комбінування між собою, їх вживання для реалізації студентами завдань самостійного читання. Крім того, обгрунтовано критерії відбору іншомовної лексики медичної галузі, наведена процедура їх відбору, в результаті якої було відібрано 750 термінологічних одиниць для опрацювання як в аудиторії, так і в процесі самостійної роботи, що увійшли до словника-мінімуму англійської фармацевтичної термінології з латинськими та українськими відповідниками (2019 р.) [15, с. 237-259].

Наступним нашим кроком $є$ методична класифікація відібраних лексичних одиниць, яка повинна бути врахована при створенні підсистеми вправ.

\section{СПИСОК ВИКОРИСТАНОЇ ЛІТЕРАТУРИ}

1. Бастрикова Е. М. Проблемы создания лексических минимумов при обучении языку специальности.
Бодуэновские чтения: Бодуэн де Куртенэ и современная лингвистика. Труды и материаль : материалы Междунар. научн. конфер. : в 2 т. / под. общ. ред. К. Р. Галиуллина, Г. А. Николаева. Казань: изд-во Казан. ун-та. 2001. Т. 2. С. 127-128.

2. Берман И. М. Методика обучения английскому языку в неязыковых вузах. Москва : Высшая школа, $1970.232 \mathrm{c}$

3. Вишнякова Н. Г. Терминологическая лексика, методика и принципы ее отбора для обучения иностранному язику в технических вузах : автореф. дис ... канд. пед. наук : 13.00.02 / МГПИ им. В. И. Ленина. Москва, 1966. 20 с.

4. Горпініч Т. І. Особливості іншомовних фахових джерел як засобу навчання читання іноземною мовою (на прикладі професійної літератури з фармації). Молодий вчений. 2015. № 2. С. 222-225.

5. Митрофанова К. А. Обучение иноязычной лексике медицинской сферы студентов-медиков : дис. ... канд. пед. наук : 13.00.02 / ГОУ ВПО «Уральский гос. пед ун-т». Екатеринбург, 2010. 168 с.

6. Пассов Е. И. Коммуникативный метод обучения иноязычному говорению. Москва : Просвещение, 1991. 223 с.

7. Рахман С. Е. Система работы по формированию лексических навыков чтения : дис. ... канд. пед. наук : 13.00.02 / Липецк. гос. пед ин-т. Липецк,1984. 173 с.

8. Семенчук Ю. О. Формування англомовної лексичної компетенції у студентів економічних спеціальностей засобами інтерактивного навчання : дис. ... канд. пед. наук : 13.00.02 / Київ. нац. лінгв. ун-т. Київ, 2007. 280 c.

9. Кравченко А. Добір лексичного та текстового матеріалу для диференційованого формування у майбутніх філологів англомовної лексичної компетентності в читанні. Наукові записки Тернопільського національного педагогічного університету ім. В. Гнатюка. Серія «Педагогіка». Тернопіль, 2018. Вип. 2. С. 100-107.

10. Палецька-Юкало А. В. Методика формування німецькомовної лексичної компетентності майбутніх учителів на основі автентичних художніх творів : дис. ... канд. пед. наук : 13.00.02 / Терноп. нац. пед ун-т ім. Володимира Гнатюка. Тернопіль, 2018. $405 \mathrm{c}$.

11. Шамов А. Н. Когнитивный подход к обучению лексике: моделирование и реализация (базовый курс немецкого языка) : дис. ... д-ра пед. наук : 13.00.02 / Нижегородский гос. лингв. ун-т им. Н. А. Добролюбова. Нижний Новгород, 2005. 537 с.

12. Hutchinson T., Water A. English for Specific Purposes. Cambridge: Cambridge University Press, 1987. 183 p.

13. Rusalkina L. G. Integration of professional and linguistic disciplines of foreign-language orientation in the educational process of higher medical schools. European Journal of Humanities and Social Sciences. 2018. № 6. P. 93-96.

14. Zadoroshna I. П. Developing Language Learning Strategies and Self-Evaluation Skills as Key Factors in Promoting Prospective FL Teachers' Autonomy. Педагогічний альманах: збірник наукових праць. 2016. Вип. 29. С. 69-75.

15. Tomashevska A. Teaching ESP language of future pharmacists via content: Reading and Vocabulary. News of Science and Education. Sheffield, 2017. Vol. 8 (56). P. $46-50$.

Дата надходження до редакиіï: 02.11.2020 p. 